\title{
Physicochemical, Mechanical and Morphologic Characterization of Purple Banana Fibers
}

\author{
Ana Paula Bispo Gonçalves ", Cleidiene Souza de Miranda ${ }^{a}$, Danilo Hansen Guimarães ${ }^{a}$, \\ Jamerson Carneiro de Oliveira ${ }^{a}$, Allan Moreira Faislon Cruz $z^{a}$, Felipe Leonardo Brito Melo da Silva,
} Samuel Luporini ${ }^{a}$, Nadia Mamede Josét

\author{
aPrograma de Pós-graduação em Engenharia Química, Universidade Federal da Bahia-UFBA, \\ Rua Aristides Novis, 2, Federação, CEP 40210-630, Salvador, BA, Brasil
}

Received: December 12, 2014; Revised: October 10, 2015

\begin{abstract}
Weather conditions and the Brazilian fertile soil contribute to abundant natural resources in a wide variety of fiber types. These fibers have attracted interest in Materials Science area for such characteristics as: low cost, high elasticity modulus and renewability. In this context, the objective of this work was physical, chemical and morphological characterization of purple banana fibers (Musa velutina). The following characterizations were employed: TG, DSC, FTIR, XRD, SEM, density, mechanical properties and chemical composition. The results showed that the purple banana fibers had good thermal, mechanical, morphological and structural properties. Treatment with sodium hydroxide was efficient in removing amorphous regions present on the fiber as evidenced by the chemical composition, increasing the crystallinity index. Therefore, the purple banana fiber is promising as reinforcement in polymer matrices.
\end{abstract}

Keywords: purple banana, vegetable fibers, mercerization, characterization

\section{Introducion}

The increasing substitution of synthetic fibers by lignocellulosic fibers, it's a response to the concern in the development of materials through technologies that enable the use of products that cause less environmental impact. Vegetable fibers, when incorporated into polymers, can be processed by many conventional methods, such as extrusion, injection, calendering, laminating, pressing and others ${ }^{1}$.

In this context, lignocellulosic fibers have many features that make their use beneficial, such as low density, low cost and high elasticity modulus. Also, they are nontoxic, not abrasive and are originated from renewable sources. These fibers are abundant in Brazil and can be easily modified by chemical agents, exhibiting comparable mechanical properties to other synthetic reinforcements ${ }^{2,3}$.

However, vegetable fibers have a hydrophilic nature, affecting the adhesive properties when they are incorporated in hydrophobic polymer matrices ${ }^{4-6}$. To minimize the poor adhesion with hydrophobic polymeric matrices, it is possible to modify the fiber surface with chemical methods. The chemical treatment with sodium hydroxide used in plant fibers, known as mercerization, tends to improve the adhesive characteristics, and clean the fiber surface, removing waxes, greases, and part of the hemicelluloses which is soluble in very low concentrations of alkali ${ }^{7}$.

Brazil stands out as one of the largest banana producer countries in the world. Thus, banana cultivation has been an important agricultural activity to its economy. Over the past five years, the cultivation has spread, primarily in the southeastern and northeastern regions, due to the emergence

*e-mail: anapaulabispo43@yahoo.com.br of new technologies driven by the use of raw materials, originated from renewable sources, in the automotive sector ${ }^{8,9}$.

The production conditions of banana cause a large amount of vegetable matter accumulated in the soil and create, per year, 180 to 200 tons of vegetable waste (leaves, pseudo-stems and stalk) per hectare ${ }^{10}$. The pseudostem is the main banana crop residue and, when the bunch of bananas is removed, it does not produce a new bunch, which causes it to be left in the soil and attracts bio-consumer creatures ${ }^{11,12}$.

In order to solve this problem it is necessary to look for alternatives to enhance the pseudostem of the banana as raw material. The objective of this work is to study the chemical composition, density, physicochemical characteristics, morphological and mechanical properties of banana fiber called Musa velutina, also known as the purple banana.

\section{Material and Methods}

\subsection{Materials}

The fibers of purple banana (Musa velutina) used originated from Salvador (Bahia, Brazil). The reagent employed in this study was sodium hydroxide (Vetec).

\subsection{Methods}

\subsubsection{Extraction of banana fiber}

Fibers of purple banana were obtained as raw material by brushing the pseudostem. Two batches of fibers have been separated: the first one, free of the chemical treatment, was called in natura fiber (FBRN), while the second one, subjected to the treatment with a solution of sodium 
hydroxide at $5 \%(\mathrm{w} / \mathrm{v})$ for $1 \mathrm{~h}$ at room temperature, was labeled (FBRT). These samples were washed with distilled water until it reached a $\mathrm{pH}$ of 7 and they were dried in a stove at $100{ }^{\circ} \mathrm{C}$ for $48 \mathrm{~h}$.

\subsubsection{Characterization of banana fiber}

Banana fibers were characterized by analysis of chemical composition, TG, DSC, FTIR, XRD, SEM, density and mechanical properties. The TG analysis was performed on a Shimatzu thermal-balance, model TGA-50, between 25 and $1000{ }^{\circ} \mathrm{C}$ at a heating rate of $10^{\circ} \mathrm{C} / \mathrm{min}$ under nitrogen flow. For DSC analysis it was used a Seiko equipment, model Exstar DSC-6220, where the samples were analyzed from 25 to $550{ }^{\circ} \mathrm{C}$ with a heating rate of $10{ }^{\circ} \mathrm{C} / \mathrm{min}$. For the analysis of FTIR it was used a Bomem spectrometer, model ABB Bomem MB Series in wavelength of 4000-400 $\mathrm{cm}^{-1}$. The crystallinity was analyzed on a Shimadzu X-ray diffractometer, model XRD-6000 with angles $2 \theta$ between 5 and $80^{\circ}$. The crystallinity index was calculated by:

$$
I_{c}=\left[\left(I_{(002)}-I_{(\mathrm{am}) /} I_{(002)}\right] \chi 100\right.
$$

The SEM equipment used to view the samples surface was a JEOL, model JSM-6610. The determination of banana fibers density were obtained with a helium gas pycnometer of MICROMERITICS $\AA$, Ultrapycnometer 1000 model. The tensile tests of banana fibers were performed at a Universal equipment test EMIC, DL2000 model, using a $50 \mathrm{kN}$ load cell and the test speed of $3 \mathrm{~mm} \cdot \mathrm{min}^{-1}$. The chemical composition was determined by the Tappi method T-203 cm-99 and T-222.

\section{Results and Discussion}

The results of thermal degradation of the in natura and treated banana fiber are shown in Figure 1. By analyzing the curve of thermogravimetric FBRN and FBRT samples was observed the onset of thermal degradation at $250{ }^{\circ} \mathrm{C}$ with weight loss of $85 \%$ up to $600{ }^{\circ} \mathrm{C}$. The DTG curves, Figure $1 \mathrm{~b}$ had two distinct events. The first event is related the humidity and terpenes, alcohols, esters, aldehydes, ketones, organic acids, aliphatic hydrocarbons and phenols ${ }^{13}$.

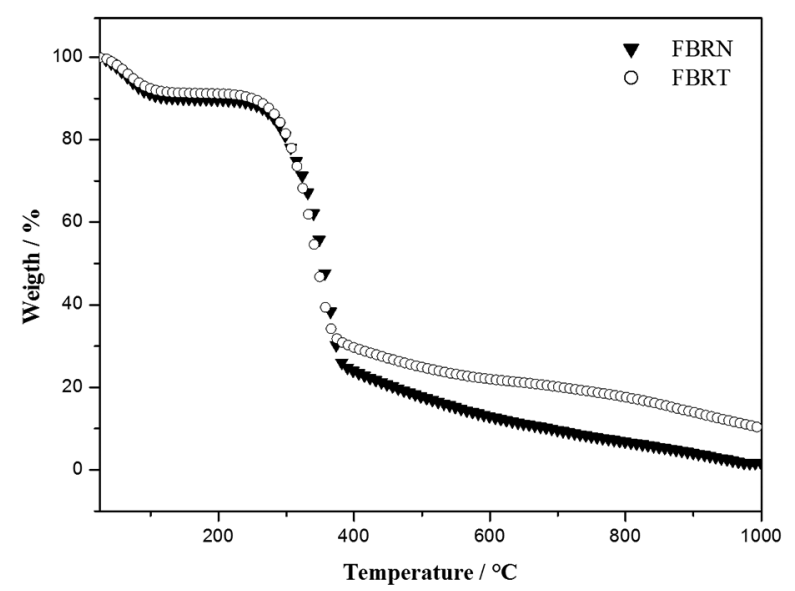

(a)
The second event is related to the holocellulose degradation (hemicellulose + cellulose). The lignin degradation event was not observed, because of its complex structure, which degrades with very low weight loss under a temperature range of $100-900{ }^{\circ} \mathrm{C}^{[14,15]}$.

Through the DSC curves, represented by Figure 2, it is observed endothermic events attributed to the removal of humidity $\left(50\right.$ to $60{ }^{\circ} \mathrm{C}$ ) for FBRN and FBRT, respectively. Based on this analysis it was also observed exothermic peaks associated with the decomposition of hemicellulose and lignin around 275 and $365^{\circ} \mathrm{C}$, respectively. These events are superimposed to the endothermic decomposition of cellulose around 341 and $363{ }^{\circ} \mathrm{C}$, for the treated and in natura fibers, respectively. Comparing the DSC curves of the FBRN with FBRT sample, it is possible to see the decrease of the second event. This behavior may be related to the partial removal of the impurities and some constituents of the fiber, like hemicelluloses and lignin.

To confirm the presence of functional groups and the removal of components present in banana fiber after the alkaline treatment, it was carried a FTIR analysis, illustrated in Figure 3. As all vegetable fibers, banana fiber is mainly composed by alkenes, esters, aromatics, ketenes and alcohols. The presence of the band $3400 \mathrm{~cm}^{-1}$ is associated with the presence of the $\mathrm{OH}$ group, the band at $2920 \mathrm{~cm}^{-1}$ is related to the $\mathrm{CH}$ group, the one at $1635 \mathrm{~cm}^{-1}$ is due to the stretching of the $\mathrm{C}=\mathrm{C}$ group of benzene ring, the region between $1765-1715 \mathrm{~cm}^{-1}$ refers to the functional group $\mathrm{C}=\mathrm{O}$, in $1058 \mathrm{~cm}^{-1}$ it is observed the band related to the stretching of the C-O-C group and in $1050 \mathrm{~cm}^{-1}$ occurs the stretching of the $\mathrm{C}-\mathrm{O}-\mathrm{H}$ group ${ }^{14}$. The most noticeable effect of alkaline treatment on banana fiber in FTIR spectra is the disappearance of the bands $1735 \mathrm{~cm}^{-1}$, regarding to the presence of the carbonyl $(\mathrm{C}=\mathrm{O})$, and $1247 \mathrm{~cm}^{-1}$, associated with the carboxylic acid $(\mathrm{COOH})$. These groups are presented in the structure of the hemicelluloses and lignin ${ }^{15}$. Comparing the spectra of the treated fiber and the in natura fiber, it is noticed the disappearance of the bands at $1735 \mathrm{~cm}^{-1}$ with the alkali treatment, attributed to vibrational modes of $\mathrm{C}=\mathrm{O}$ and $\mathrm{C}-\mathrm{O}$ groups present in lignin and hemicellulose,

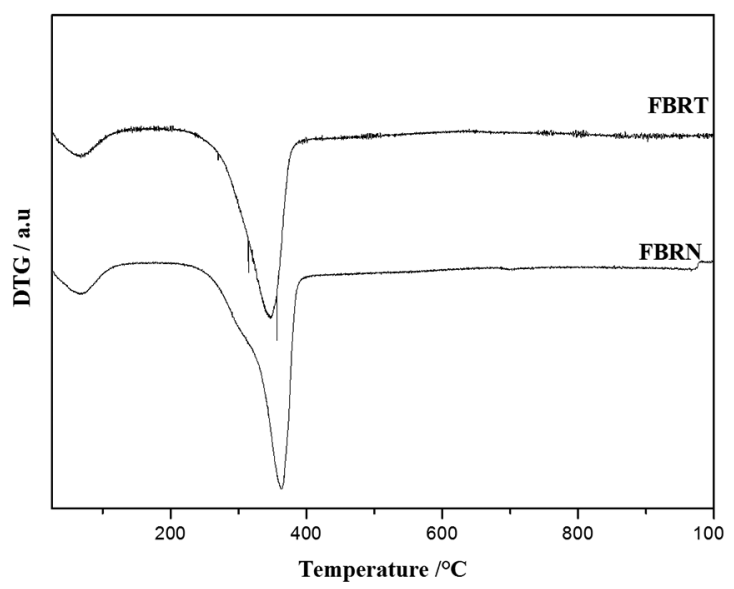

(b)

Figure 1. (a) TG; (b) DTG curves of purple banana fibers in natura and treated. 
which were partially removed during the mercerization, as illustrated in Figure 3.

The Figure 4 illustrates the X-ray diffraction concerning FBRN and FBRT samples. They are similar to those reported in the literature for other vegetable fibers, which mainly exhibit a cellulosic structure ${ }^{15}$. Samples showed peaks related to the

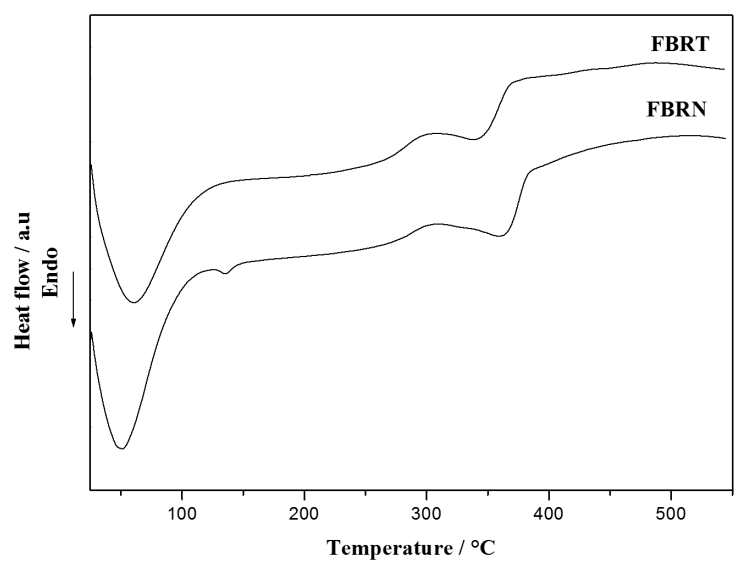

Figure 2. Differential scanning calorimetry curves.

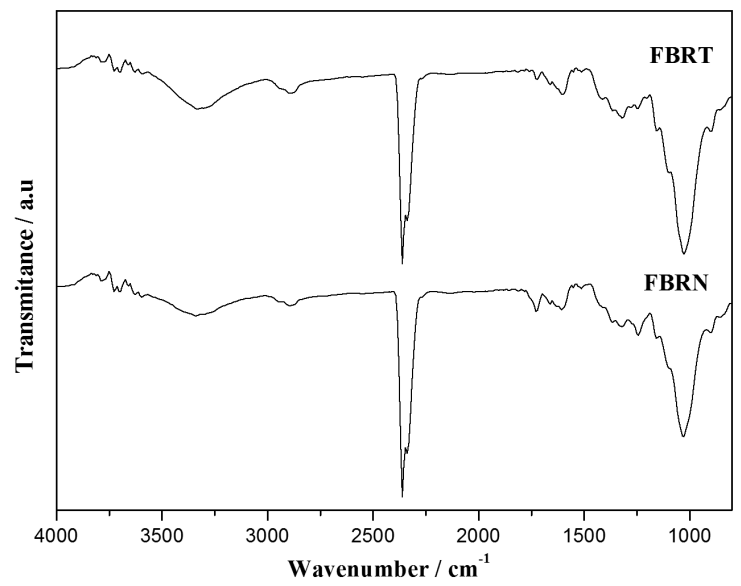

Figure 3. FTIR analysis of purple banana fibers in natura and treated.

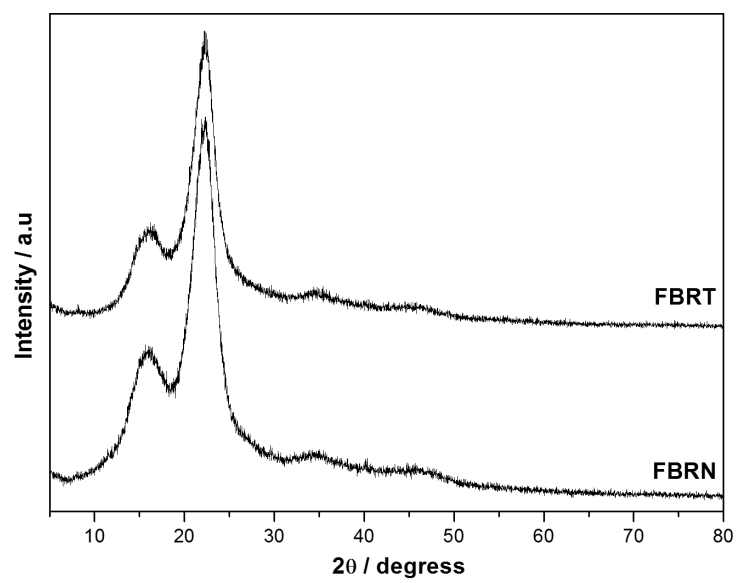

Figure 4. XRD curves of purple banana fibers in natura and treated. characteristic crystal planes of lignocellulosic materials in $2 \theta=22^{\circ}$ corresponding coordinate plane of reflection (002). These plans are relacioados network of glycosides celulose rings. In both samples was observed two halos $2 \theta=16^{\circ}$ and $2 \theta=35^{\circ}$ related to the planes $(101)$ and $(040)$ corresponding to the amorphous portion in microfibriles (hemicellulose and lignin $)^{15}$. By analyzing the crystallinity index of the samples (Table 1), high values were observed, probably due to the high content of cellulose. Comparison of crystallinity index values promoted the observation of an increase in this index in the treated fiber, so it can be inferred that the partial removal of some of its components (lignin and hemicellulose) increases the degree of crystallinity, promoting a better packing of cellulose chains ${ }^{16}$.

The micrographs of the surface of in natura and treated purple banana fibers are illustrated in Figure 5. The banana fibers generally have a rough surface, a common behavior of vegetable fibers that have high content of cellulose. The FBRN sample (Figure 5a) has a more irregular surface when compared to FBRT sample (Figure 5b). This irregularity may be attributed to the presence of impurities, waxes, hemicelluloses and lignin on its surface. The fibers that were subjected to mercerization process showed reduction of the surface layer of these impurities: waxes, that are less stable components, and possibly part of the lignin and hemicelluloses, which act as carburizing agents in vegetable fibers ${ }^{17}$. Hence, it implies an increase of the cellulose exposition on the fiber surface, making the microfibers become more exposed, thereby increasing the number of possible reactions ${ }^{18}$.

The density values of in natura banana fibers (FBRN) and treated (FBRT) are included in Table 1. Based on these values, it can be seen that these fibers exhibit lower values of densities when compared to synthetic fibers, such as carbon $\left(1.88 \mathrm{~g} / \mathrm{cm}^{3}\right)$, glass $\left(2.55 \mathrm{~g} / \mathrm{cm}^{3}\right)$ and steel $\left(7.85 \mathrm{~g} / \mathrm{cm}^{3}\right)^{[19]}$. However they are similar to those of other vegetable fibers whose values are $1.25 \mathrm{~g} / \mathrm{cm}^{3}, 1.03 \mathrm{~g} / \mathrm{cm}^{3}, 1.35 \mathrm{~g} / \mathrm{cm}^{3}$, $1.45 \mathrm{~g} / \mathrm{cm}^{3}, 1.40 \mathrm{~g} / \mathrm{cm}^{3}$ and $1.35 \mathrm{~g} / \mathrm{cm}^{3}$ respectively for the coconut, palm, licuri, sisal and banana fiber ${ }^{18,20-24}$. The low density of plant fibers is interesting for industrial because of the possibility of producing lighter weight materials, which is a key property for determining technological applications for natural fibers ${ }^{6,25}$. For the samples of banana fiber evaluated in this study, there was a small increase in the density of the fiber after the alkali treatment. This behavior can be attributed

Table 1. Elasticity modulus values, maximum stress, specific deformation, crystallinity index, density and chemical composition for the purple banana fiber.

\begin{tabular}{ccc}
\hline Sample & FBRN & FBRT \\
\hline$\sigma(\mathrm{MPa})$ & $294.2 \pm 210.8$ & $375.5 \pm 131.5$ \\
$\mathrm{E}(\mathrm{MPa})$ & $22472.5 \pm 13372.2$ & $10378.0 \pm 2637.6$ \\
$\varepsilon(\%)$ & $1.42 \pm 0.34$ & $6.39 \pm 1.92$ \\
$\mathrm{I}_{\mathrm{c}}(\%)$ & 65 & 67 \\
$\rho\left(\mathrm{g} / \mathrm{cm}^{3}\right)$ & 1.22 & 1.26 \\
Celullose $(\%)$ & 63.05 & 65.24 \\
Hemicellulose $(\%)$ & 25.10 & 16.07 \\
Lignin $(\%)$ & 9.01 & 3.01 \\
\hline
\end{tabular}




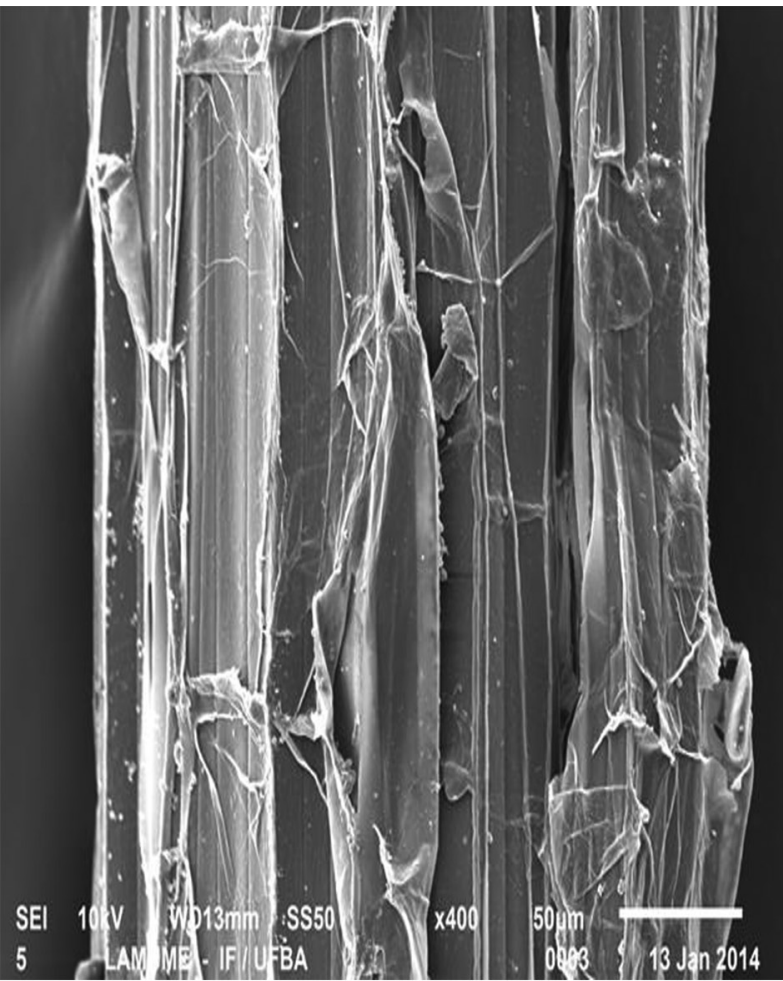

(a)

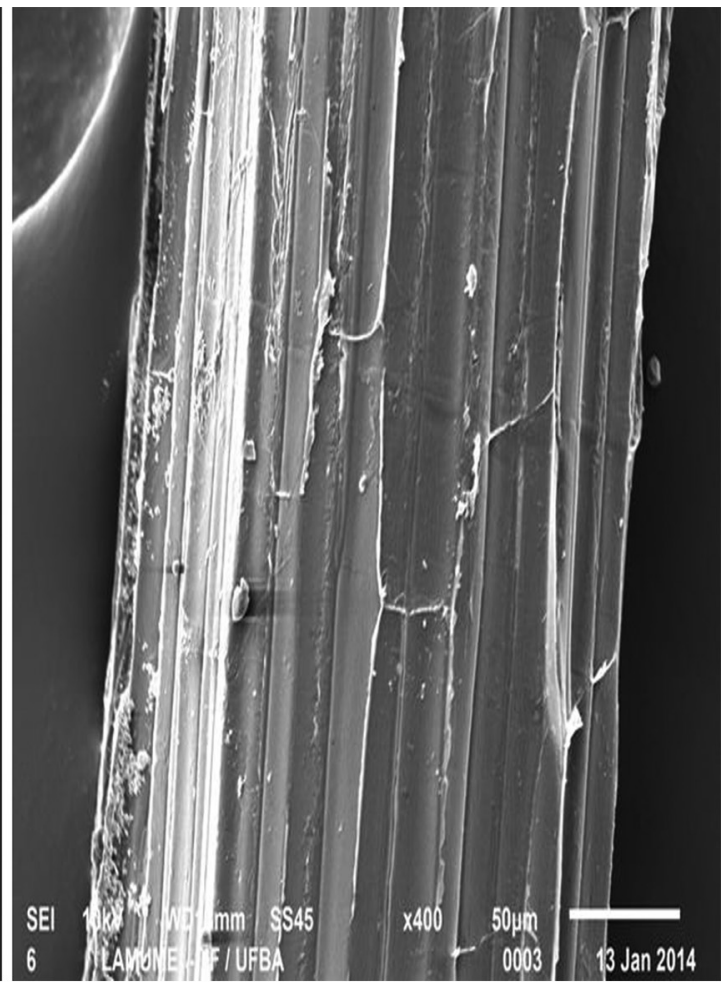

(b)

Figure 5. Micrographs of the surface of purple banana fibers in 400x in natura (a); treated (b).

to the presence of residual sodium and the amount of crystals present on the fiber surface resulting from the treatment.

The Table 1 shows the values of tensile strength, young's modulus and strain for the tensile test. Based on the results it was found that FBRT sample is toughest than FBRN. The alkaline treatment gives little improvement in tensile strength of the treated fiber. A comparison with published results showed that the purple banana fiber showed higher tensile strength values than other species of banana (Musa Sapientum, Musaceae) whose tensile strength is $2339 \mathrm{MPa}^{[26]}$. These different values may be associated with the type of species, soil and climate conditions. According to the literature, variation in tensile strength and Young's modulus are directly related to the variation of crystallinity index. The more cellulose present in the fibers most crystalline it will be $\mathrm{be}^{27}$. This behavior confirms the results of XRD, because the increase of the crystalline domains as seen by XRD contributes to better mechanical performance of the treated fiber. Analyzing the values of Young's modulus, it was observed that the original fiber showed a higher value for this parameter compared to the treated fiber. This may be attributable to the lignin content of the fiber is greater in the sample that was not treated. Concentration, time and temperature of treatment are factors that cause intense defibrillation in the fibers that can contribute to decreasing the resistance. Specific elongation at break for the treated sample was higher compared to untreated. These results prove the partial removal of fiber constituents provides greater flexibility and is consistent with the SEM images.
The percentual results of holocellulose, cellulose, hemicellulose and lignin of the samples are summarized in Table 1. High cellulose content and low lignin content were found, which matches with light color of the fiber. Light fibers tend to have high cellulose content, while dark fibers have a high lignin content. Comparing the fiber treated with the fiber stock, it was observed that the amount of cellulose present in the fibers increased for the treated fiber and was also observed a decrease in the percentage of lignin and hemicellulose. These results confirm what was analyzed by the techniques of FTIR, XRD and SEM. These data confirm the partial removal of hemicellulose and lignin after the mercerization process

\section{Conclusion}

In this study it was observed, through thermal analysis of TG and DSC, events regarding to the degradation of the constituents of lignocellulosic materials present in banana fibers. The scanning electron microscopy showed that the alkaline treatment removed impurities of the fiber, which can be verified throught the analysis of FTIR, XRD and chemical composition, which revealed the removal of some of its components, such as hemicellulose and lignin. It was found lower density values for banana fiber, which makes this material an alternative with regard to synthetic fibers, a low-cost option and an environmentally friendly material.

\section{Acknowledgements}

The authors thank CNPq, FAPESB, CAPES and PPEQ. 


\section{References}

1. Pires EN. Efeito do tratamento superficial em fibras de coco no comportamento mecânico de compósitos de matriz epoxídica. [Dissertation]. Florianópolis: Universidade Federal de Santa Catarina; 2009.

2. Catto AL, Stefani BV, Ribeiro VF and Santana RMC. Influence of coupling agent in compatibility of post-consumer hdpe in thermoplastic composites reinforced with eucalyptus fiber. Materials Research. 2014; 17(Suppl 1):203-209. http://dx.doi. org/10.1590/S1516-14392014005000036.

3. Castro CDPC, Dias CGBT and Faria JAF. Production and evaluation of recycled polymers from açaí fibers. Materials Research. 2010; 13(2):159-163. http://dx.doi.org/10.1590/ S1516-14392010000200007.

4. Gelfuso MV, Silva PVG and Thomazini D. Polypropylene matrix composites reinforced with coconut fibers. Materials Research. 2011; 14(3):360-365. http://dx.doi.org/10.1590/ S1516-14392011005000056.

5. Chianelli-Junior R, Reis JML, Cardoso JL and Castro PF. Mechanical characterization of sisal fiber-reinforced recycled HDPE composites. Materials Research. 2013; 16(6):1393-1397. http://dx.doi.org/10.1590/S1516-14392013005000128.

6. Becker D, Kleinschmidt AC and Balzer PS. Banana fibers and rigid PVC composites: effect of fiber treatment. Matéria. 2014; 19(3):257-265.

7. Jesus MS, Sousa TB, Mori FA, Guimarães BMR. Fibras vegetais com potencial para reforço de compósitos poliméricos analisados a partir da Microscopia Eletrônica de Varredura MEV. O Papel. 2015; 76(8):61-63.

8. Soffner MLAP. Produção de polpa celulósica a partir do engaço de bananeira. [Dissertation]. Piracicaba: Universidade de São Paulo; 2001.

9. Araújo JR. Compósitos de polietileno de alta densidade reforçados com fibras de curauá obtido por extrusão e injeção. [Dissertation]. Campinas: Universidade Estadual de Campinas; 2009.

10. Instituto Biológico. São Paulo. Available from: $<$ http://www. institutobiologico.sp.gov.br>. Access in: 4 Aug. 2014.

11. Bastos DC. Estudo da redução da hidroficilidade de filmes biodegradáveis do amido de milho termoplástico com e sem reforço de fibra de bananeira através do tratamento por plasma de SF6. [Thesis]. Rio de Janeiro: Universidade Federal do Rio de Janeiro; 2010.

12. Kalia S, Kaith BS and Kaur I. Pretreatments of natural fibers and their application as reinforcing material in polymer composites: a review. Polymer Engineering and Science. 2009; 49(7):12531272. http://dx.doi.org/10.1002/pen.21328.

13. Di Benedetto RM. Influência da radiação ultravioleta nas propriedades físico-químicas e mecânicas de fibras de bananeira: um método alternativo de tratamento fotoquímico. [Dissertation] Itajubá: Universidade Federal de Itajubá; 2015.

14. Yang H, Yan R, Chen H, Lee DH and Zheng C. Characteristics of hemicellulose, cellulose and lignin pyrolysis. Science Direct. 2007; 86:1781-1788.

15. Miranda CS, Fiuza RP, Carvalho RF and José NM. Efeito dos tratamentos superficiais nas propriedades do bagaço da fibra de piaçava Attalea funifera martius. Quimica Nova. 2015; 38:161-165.

16. Pereira ALS. Nanocompósitos baseados em PVOH e nanocristais de celulose obtidos de pseudocaule de bananeira. [Dissertation]. Fortaleza: Universidade Federal do Ceará; 2013.

17. Zimmermann EGM, Turella TC, Zattera AJ and Santana RMC. Influence of chemical treatment of banana fiber composite of poly (ethylene-co-vinyl acetate) with and without blowing agent. Polymer Science and Technology. 2014; 24(1):58-64.

18. Fagury RVG. Avaliação de fibras naturais para a fabricação de compósitos : acaí, coco e juta. [Dissertation]. Belém: Universidade Federal do Pará; 2005.

19. Mano EB. Polímeros como materiais de engenharia. 2 nd ed. São Paulo: Edgar Blucher; 2000.

20. Silva RV. Compósito de resina poliuretano derivada de óleo de mamona e fibras vegetais. [Thesis]. Belém : Universidade Federal do Pará; 2003.

21. Satyanarayana KG, Guimarães JL and Wypych F. Studies on lignocellulosic fibers of Brazil. Composites. Part A, Applied Science and Manufacturing. 2007; 38(7):1694-1709. http:// dx.doi.org/10.1016/j.compositesa.2007.02.006.

22. Deepa B, Abraham E, Cherian BM, Bismarck A, Blaker JJ, Pothan LA, et al. Structure, morphology and thermal characteristics of banana nano fibers obtained by steam explosion. Bioresource Technology. 2011; 102(2):1988-1997. http://dx.doi.org/10.1016/j. biortech.2010.09.030. PMid:20926289.

23. Miranda CS. Sintese e caracterização de poliésteres e compósitos reforçados com fibra de piaçava. [Dissertation]. Salvador: Universidade Federal da Bahia; 2011.

24. Oliveira JC. Síntese e caracterização de nanocompósitos poliméricos reforçados com whiskers de celulose da fibra de licuri. [Dissertation]. Salvador: Universidade Federal da Bahia; 2015.

25. Taipina MO, Ferrarezi MMF and Gonçalves MC. Morphological evolution of curauá fibers under acid hydrolysis. Cellulose. 2012; 19(4):1199-1207. http://dx.doi.org/10.1007/s10570-0129715-3.

26. El Banna WR, Fujiyana R, Santos IP and Pereira LCO. Fibra de bananeira como material de Engenharia. In: Anais do XXIX COBENGE; 2011; Blumenau, SC. Brasília: ABENGE; 2011.

27. Martin AR, Martins MA, Mattoso LHC and Silva ORRF. Treatment effect of in properties fibers do biocomposite thermoplastic starch/Polycaprolactone/Sisal. Polimeros. 2011; 19:217-222. 